\title{
Solar Energy as Emergency Power Resource, the Design Specifications and Requirements
}

\author{
Demet Irkli Eryildiz ${ }^{1} \&$ Marim M A Baka ${ }^{2}$ \\ demet.eryildiz@okan.edu.tr ${ }^{1} \&$ belybeke1990@gmail.com ${ }^{2}$ \\ Istanbul Okan University \\ Institute of Graduate Studies, Istanbul, Turkey
}

\section{ABSTRACT}

The energy demand expansion which triggered large establishment cost has promoted the deployment of renewable energies in residential as well as industrial premises. In many countries such as Libya where sun is active most of the times in a year, establishment of PV based power plant is profitable investment. Another problem is manifested by the fluctuation in main electricity suppliers which fail to maintain continuous power generation. Customers are facing big challenges in finding alternative power generators to run home appliances. In this paper, we found that green homes design where PV station can be considered while performing the architecture design of residential premises. The design specifications and requirements for the same is being illustrated in this paper.

\section{Keywords: Solar Energy, Power Generation, Inverter, Photovoltaic, Renewable Energy.}

\section{INTRODUCTION}

Buildings consume high energy through their lifecycle, where energy is used to obtain the building in its final form, live it them, and finally in the end of its life; given the impressive numbers building the energy consumed very high, especially with the increase in population and the excessive need for buildings [1]. While according to Din the burdening's needs for energy

represented by: Provide thermal comfort, lighting, equipment operation and all infrastructure requirements [2]. According to Elkady, buildings consumes about $41 \%$ of the producing electrical energy, most of which is consumed in the building's supply of ventilation, cooling in the summer and heating during the winter, and lighting. And if added the consumption of construction and manufacturing operations in addition to the energy embodied in the building materials themselves, the share of buildings in energy consumption increases to about 50\%, which is responsible for $45 \%$ of the total carbon dioxide emissions. Here, architects are responsible for the consumption patterns in their designs. Building materials are considered one of the main requirements of architecture and there are many studies focusing on estimating the energy consumed in the production of building materials where most of this energy is electrical and thermal, while According to Din, the construction phase includes the use of materials such as concrete, steel, bricks, and insulation materials, as producing them consume high energy. This type of embodied energy represented the amount of energy consumed to extract, purify, treat, transfer and manufacture these materials. Which classified in basis on energy consumption for production into three sections [2]: High energy materials whose energy consumption exceeds 5 GJ / ton, Medium energy materials whose energy consumption between 0.5 to 5 GJ / ton, Low energy materials whose energy consumption than $0.5 \mathrm{GJ} /$ ton. As mentioned above, this energy is consumed only in the construction process, but there are quantities of energy consumed in operations such as for refrigeration, heating, lighting and equipment operation. In this stage it's possible to improve the efficiency of buildings in energy consumption through two basic methods. 
The first depends Modern technologies in obtaining clean energy such Photovoltaic systems. The second adopts natural design solutions to raise the degree of compatibility of the building with the surrounding environment, called passive energy design.

\section{ENERGY RESOURCES}

Derived from natural resources Including wind, air, solar, water, or wave and biomass energy, this type of energy is inexhaustible and that what distinguishing it from the non-renewable energy.

Renewable energy does not excrete carbon dioxide, harmful gases or increase the greenhouse effect, as happens when burning fossil fuels and nuclear reactors. Currently, most renewable energy produced in hydroelectric plants by great dams in rivers and watersheds, Also Wind and solar energy methods are widely used in some developing countries; electricity production using renewable energy are more common in recent times, where several countries plans to increase their production of renewable energy to cover their energy needs by $20 \%$ of their consumption in 2020 [3].

Renewable energy and energy efficiency are the two main pillars for achieving the desired transformation in the energy sector. While the various paths are able to reduce climate change, and they are the optimal path to achieve the majority of the required reduction in gas emissions as quickly as they can together achieve more than $90 \%$ of the required reductions in gas emissions as quickly as necessary, using safe, reliable, affordable and widely available technologies [4].

With comprehensive policies in place, the transformation of the energy system can significantly boost employment rates in the energy sector. In general, the move to renewables will create jobs in the energy sector that outnumber the jobs that the fossil fuel sector will lose. The "Renewable Energy Roadmap" report predicts that the transformation of the energy system will result in the loss of 4.7 million jobs in the fossil fuel sector by 2050 , but in return it will create 19 million new jobs in the fields of renewable energy, energy efficiency, network improvement, energy resilience, in all, this means 11.6 million jobs. In order to meet the human resource needs in the fields of renewable energy and energy efficiency within the framework of this rapid expansion, education and training policies must meet the skills required for these two sectors by creating the local value to the maximum extent [4]. The hydroelectric energy: obtained by using water flow in the direction of the turbines blades, which leads to its circulation, which in turn generate energy. The hydroelectric energy is one of the important sources of renewable energy supplies in the world, with the total electrical energy derived from hydropower reaching 3700 terawatt hours per hour, topped by China at 864 terawatt hours per hour. The wind Energy: used to generate electricity, by converting kinetic energy into electrical energy. Machines that generate electricity are called wind turbines. The global installed capacity of wind energy is $283 \mathrm{GW}$ in 2012. Geothermal energy: It is the heat stored under the surface of the earth that can be exploited by contact and thermal transfer, which can be exploited in the form of direct heat or converted into electrical energy. The amount of energy produced globally was estimated at 223 terawatt / hour. Bioenergy: obtained from plants and animals by converting them into liquid or gas by chemical methods or pyrolysis. Among the most important types of bioenergy are the production of methane, alcohol and organic fertilizers. The total installed capacity of biofuels in the world reached $83 \mathrm{GW}$. Nuclear energy: produced by the nuclear fission of an atomic nucleus through nuclear reactors. The number of nuclear reactors producing energy was estimated at 439 in 31

Page Number: 11 - 30 
countries producing approximately $14 \%$ of the electric energy in the world.

\section{PHotovoltaic (PV) CELLS}

Photovoltaic consists of two words: (photo) which is a word from the Greek roots meaning light and (voltaic) which is a unit used to measure electrical energy, so Photovoltaic means electricity generated by sunlight [5]. It is an electronic device that converts direct solar energy into continuous electrical energy by the photovoltaic phenomenon. While exposed to light, producing a difference in the voltage inside which produces a continuous current (Solar Energy Glossary).

Photovoltaic (PV) cells usually made of silicone, which considering a good way to produce electricity directly in a clean, non-polluting, unobtrusive way and without occupying space inside the building. The efficiency of these cells increases exponentially with the amount of solar radiation with its shedding; and decreases as the temperature increases [6]. The generated electricity is either used directly or converted using transformers to in DC devices. Also could be stored in batteries for use during the night when solar cells do not produce electricity.

In 1839 Alexander Edmund Becquerel noticed the photoelectric effect (PV) via an electrode in a conductive solution exposed to light, and this was the starting point that led to the invention of the solar cells. Where the installation of the first solar cell made of selenium (se) in 1883 by the scientist Fritts and he expected to have a role in the production of electricity in the future [7]. Bell Labs announced a solar silicon cell in 1954 with patents to Pearson, Chapin, and Fuller. Then, first application of solar cells was on space satellites, where the first satellite operated by silicon solar cells was launched in 1962, after that the Silicon cells were developed for civilian use in the 1970s, and the oil crises in 1973 speed up the beginning in solar plant [8].
After that period, development research in the physical and engineering sciences of semiconductors increased in particular, in connection with the study of photovoltaic exchanges, the development of photovoltaic cells and their technologies improved their efficiency, as production doubled dozens of times from 1992 to 2013 as shown in the figure [8].

The trend towards renewable energy increased the produced photovoltaic cells, which in turn decreased their cost, since the watt cost in 1977 was approximately $\$ 76.67$, it became $\$ 0.74$ in 2013 as shown in the figure [9]:

The cost decreasing continued where according to the International Renewable Energy Agency report in 2018 [4].

\section{PHOTOVOLTAIC (PV) CELLS TYPES}

Photovoltaic cells are made of materials with high properties to absorb the solar radiation, usually named by its manufactured materials; its manufacturing methods differs according purpose, for example the cells for the space use differs from the earth use. Solar cells are divided into three generations: the first generation is called conventional cells which are silicon crystalline cells, the second generation are amorphous silicon thin (CdTe and CIGS) cells, and the third generation is the thin film membrane cells. Where the first and second generation cells are the common and the third is still under research and development [10].

\section{SINGLE-CRYSTAL SILICON (MONOCRYSTALLINE)}

This cell is one of the oldest cells and most popular. It is a cell cut from the silicon crystal into thin sheets with high-precision techniques. Since all cells are cut from one crystal in one direction, they have a uniform color that ranges from blue to 
black, yet there are cells of other colors such as golden and distinct purple. In spite of the high efficiency of this type, the color cells lose their efficiency by $20 \%$, because they reflect some of the solar radiation that falls on them, so the designer will need more solar panels. As for the thickness of these cells, it is approximately $10 \mathrm{x}$ $10 \mathrm{~cm} 2$ and 350 microns [11][12]Figure 1 describes the Monocrystalline.

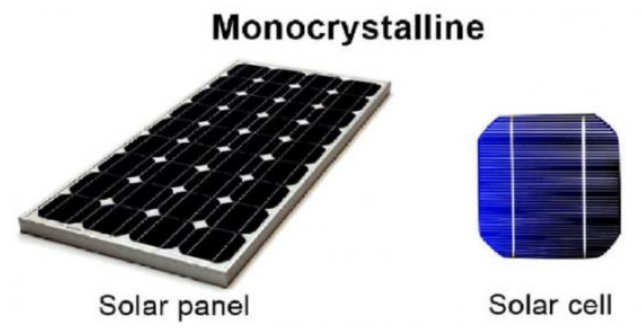

Figure 1: Single-crystal silicon (Monocrystalline)[10].

\section{MULTI-CRYSTAL SILICON (POLYCRYSTALLINE)}

Scraping from the cylindrical silicon crystal in different directions, which gives it irregular shape and a single gradient color usually blue, but there are other colors such gray which less efficient; this cell is treated chemically in special ovens to increase their electrical properties. its efficiency laser than monocrystalline silicon cells, due to the silicon purity in the cells, however this type is one of the most prevalent types due to its lower cost [3] [9]. Figure 2 describes the Polycrystalline.

\section{INTEGRATION OF PV SYSTEMS WITH BUILDINGS}

The solar energy systems have many models, one of them is converting buildings from the traditional energy-consuming to energy-saving, beside the architect's ability to make the solar modules as architectural element has an impact on the exterior of the building in terms of aesthetic and functional value.

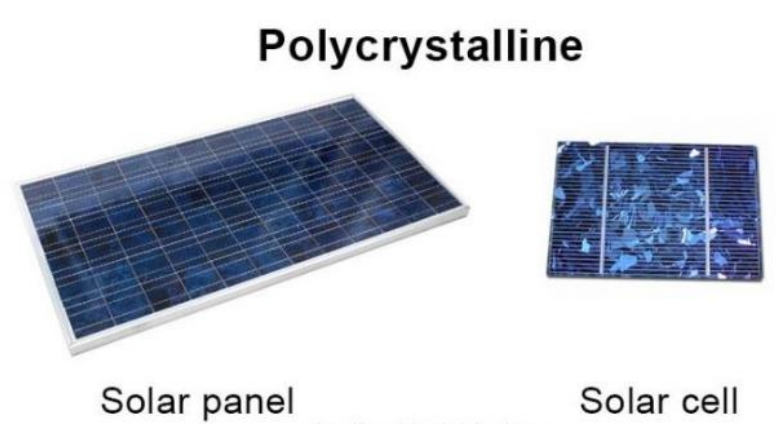

Figure 2: Multi-crystal silicon (Polycrystalline). [10].

\section{AMORPHOUS SILICON}

Considering one of the latest technologies for thin cells, and one of the most striking for designers is due to its light weight, possibility of formation without structures, and available in several colors; where it is made by depositing silicon with a thin layer of up to 200 microns on the surface of the plastic or glass. This type efficiency is very small ranging from 5 to $8 \%$ but it is less expensive comparing to previous types [9] [13] The following Figure 3 describes the amorphous silicon.

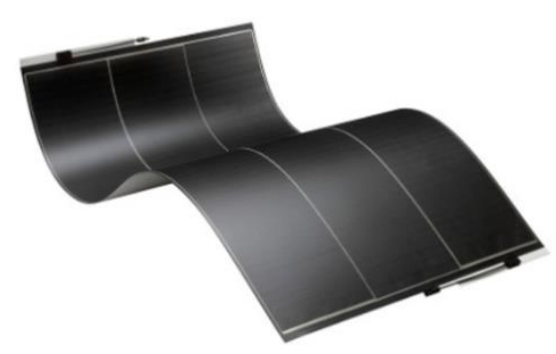

Figure 3: Amorphous silicon [13]

The integration of solar systems into architecture is considering primary challenge for many architects, since this integration with environment is a manifestation of development; and these new concepts influenced particularly the architects thinking way and globally the architecture science, besides changing the buildings from traditional to energy-saving technology [15]. On the other side the size and shape of the PV system influence on the buildings appearance, and as these systems will be widely effect on the 
building's design, and in the absence of the skills to integrate these systems into a design, the result will not be satisfactory from an architectural point

\section{BUILDING-INTEGRATED PHOTOVOLTAIC BIPV}

In this type the Photovoltaic systems integrate completely with buildings, in order to achieve the primary purpose of the modules, which is energy saving, creating an equivalence relationship between the architectural design and the functional characteristics of the photovoltaic systems. As photovoltaic modules replace traditional building materials in walls, windows, or roof; it's good to mention that this integration must enhance the aesthetic aspect of the building, the thing which studied from the beginning of the design [14].

BIPV is One of the important solutions in this field, it could be either small photovoltaic modules installed with external finishing materials or manufactured within them, its advantages the aesthetic appearance, ease of design, and light weight, as the following figure reflects the integration between the photovoltaic modules and traditional roofing materials [1] as in Figure 4:
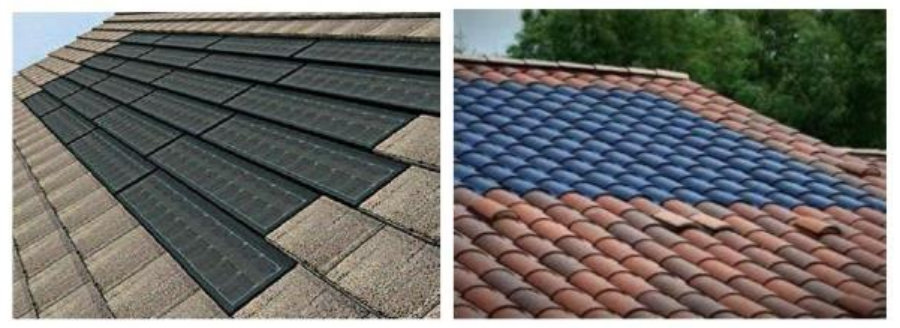

Figure 4: Photovoltaic modules and traditional roofing materials [1]

\section{BUILDING APPLIED \\ PHOTOVOLTAIC BAPV}

The PV modules not integrate with the building functionally, so they are not directly related to the structure of the building, but installed on the traditional materials of the building. They do not of view. There are many model for integrating the PV systems in the building architecture:

play the role of building materials, but it is possible to enhance the aesthetic view of the building [16], the following figure reflects the Schematic view of grid-connected BIPV and BAPV system [17] as in Figure 5.

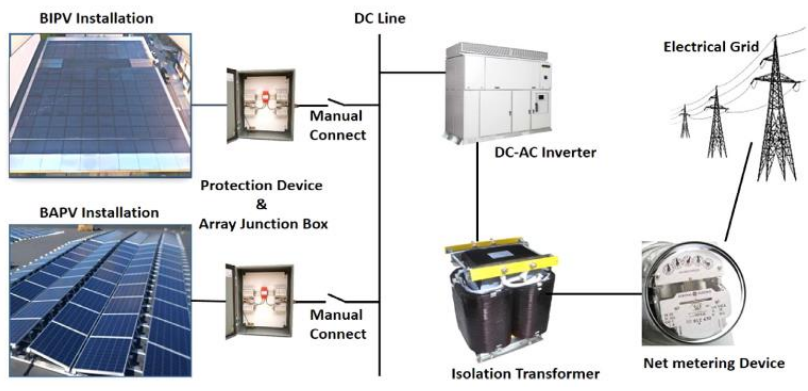

Figure 5: Schematic view of grid-connected BIPV and BAPV system [17]

\section{OPEN RACK MOUNTED PV (ORMPV)}

Which is the last type, designed to integrate the photovoltaic systems on the roofs of residential buildings, It can be installed as a parachute for shading or on the ground for energy production, the main purpose of this type is to increase the amount of electricity generation; therefore the photovoltaic modules install in the correct direction (south) and at the correct inclination angle, the following figure reflects the ORMPV installation [16] as in Figure 6.
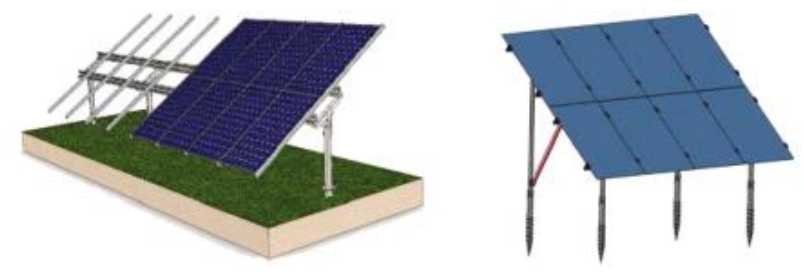

Figure 6: ORMPV installation [16] 


\section{DISCUSSIONS AND}

\section{RECOMMENDATIONS}

The sustainable architectural formation adopts the achievement of a sustainable development strategy through the close relation between environment, economy and the social dimension; as the effects of the architectural requirements on the environment have clear economic dimensions and vice versa, so the energy consumption that causes high electricity bill has a close connection to the phenomenon of sick buildings.

The term sick building syndrome refers to describing the conditions of the residents of the building and their health effects related to the time spent in the building, without the possibility of identifying a disease or a specific reason for that. The causes of sick building phenomena frequently interfere with the comfort factors related to the physical properties of the building such: air quality, carbon dioxide ratio, static electricity percentage, electromagnetic waves and high humidity. To address this phenomenon, we must go towards sustainable environmental design, or "green design". These concept is considering a solution for caring human health and environmental, besides the green building is a step further, because it does not only enhance the use of renewable natural energy but rather emphasizes the overlap between green construction and the quality of the internal environment with human health .Generally, this phenomenon arises from the greater dependence on artificial airconditioners with neglecting natural ventilation, as well as having a social impact from the lack of psychological comfort for building users, so the global trend towards rationalizing traditional energy consumption and developing the use of renewable energy sources, especially solar energy, has become a goal that must be achieved whenever It is possible.

Where architect William Reid sees that green buildings are buildings designed, implemented and managed in a manner that takes the environment into consideration and also sees that one of the interests of green buildings appears in reducing the building's impact on the environment as well as reducing the costs of its construction and operation [18].

Therefore, architects should adopt, from the beginning of the architectural designs allow providing the appropriate internal and local environment for the convenience of the users of the building by adopting the principles of sustainable architectural formation that achieve the best employment of the data of the natural environment. While solar energy comparison with other energy sources relatively simple, uncomplicated, and saving environmental, which gives it a special status in this field, especially in the next century. It's good to mention here that building beside consuming energy and resources harming the atmosphere, In USA, as example, buildings produce $38 \%$ of the $\mathrm{CO} 2$ emissions, more than other sectors in the USA. While in the European Union (EU), buildings accounts for $40 \%$ of total energy and $55 \%$ of the electricity consumption [19].

Ghaffarianhoseini et al. in their research discussed the disadvantages of sick buildings and suggested a new concept called "healthy building" while according the author "On the contrary of the sick building, the concept of healthy building has been discussed through highlighting its major promising principles including the maintenance of IAQ and thermal control, maximizing the use of daylight, providing a workplace in compliance with the occupants' ergonomics and creating opportunities for occupants to access nature. Additionally, this study redefines the concept of healthy building through including the importance of energy management in its scope, besides its capability to procure flourishing environments and assuring the occupants' health" [20]. 
With the progress of the civilization witnessed by the world, awareness has increased more about the economic and environmental consequences of global warming and the demand for the trend towards the optimal use of energy. Especially in the field of construction, and this requires radical changes in the ways in which we design and construct our buildings. And attempts to arrive at the design of strategies and technologies that enable us to use solar energy and work to reduce the demand for energy sources to stimulate sustainable development and there are many initiatives in this sector such the "Energy Zero" buildings.

The International Energy Agency (IEA) defines a zero energy building as a building with large photovoltaic (PV) cells and a photo-voltage system. The concept of zero energy includes net zero site-energy, net zero source-energy, net zero energy emissions, and net zero energy costs [19].

The objective of Net zero energy's buildings is to supply their energy requirements through a year and generate renewable energy. National Renewable Energy Laboratory in the USA suggested 4 approaches describing Net zero energy's buildings: Net zero energy's cost, Net zero energy's source, Net zero energy's buildings emissions, and net zero site energy [21] So these building minimize the need for external energy sources in order to produce their energy needs. Therefore, our buildings need to move from the stage of energy consumption to the stage of energy production. In following some suggestions to reach this goal: Conserve energy as much as possible, Increased energy efficiency, Use of positive solar systems such as solar energy and photovoltaic cells. Solar energy will be the only source of energy that sustainable buildings need in the future and its use in the sustainable architectural formation of buildings is the investment of the future.

\section{REFERENCES}

[1] Ibrahim, A, "the relation between buldings and energy consuming", center of planning and architecture studies, (2018).

[2] Din, A, "Rational Energy Consumption in Building Construction", Publisher: Noor , ISBN10: 3330851589, (2017).

[3] Khatib,M, "The role of photovoltaic in energy conservation and architectural form of Gaza strip residential buildings", the Islamic university of Gaza, Engineering faculty of architecture department, master thesis Arabic,(2015).

[4] IRENA, I,"Renewable power generation costs in 2018". Report, International Renewable Energy Agency, Abu Dhabi, (2018).

[5] Abdel Hady,M. Shata, S. Abulyla, M, “ Towards sustainable architectural formation using photovoltaics", Faculty of Engineering - Mansoura University. Article, available at, (2015).

[6] Icel, Y., Mamis, M. S., Bugutekin, A., \& Gursoy, M. I. , "Photovoltaic Panel Efficiency Estimation with Artificial Neural Networks: Samples of Adiyaman, Malatya, and Sanliurfa". International Journal of Photo energy, (2019).

[7] Gevorkian, P. ,Solar power in building design: the engineer's complete design resource (No. Sirsi) i9780071485630), (2008).

[8] Fraas, L. M. ,History of solar cell development. In Low-Cost Solar Electric Power (pp. 1-12). Springer, Cham,(2014).

[9] Miloud N, "design of a hybrid solar powered system to supply electricity to a farm", Academy of Graduate Studies - Electric engineering, Libya, Master thesis,(2015).

[10] Bagher, A. M., Vahid, M. M. A., \& Mohsen, M. "Types of solar cells and application". American Journal of optics and Photonics, 3(5), 94,(2015).

[11] Ranabhat, K., Patrikeev, L., Antal'evna-Revina, A., Andrianov, K., Lapshinsky, V., \& Sofronova, E., " An introduction to solar cell technology". Journal of Applied Engineering Science, 14(4), 481-491,(2019).

[12] Semahi S,"The effectiveness of the performance of solar PV cells in Ouargla and the effect of intensity Solar radiation and climatic factors on it", Kassadi University of Merbah and Ouargla, physics department Master thesis,(2016)

[13] Sendy A , "What are thin film solar panels, how do they work and why aren't they used for residential solar systems?" , solar-estimate organization, (2019). available at:

[14] Strong. S, "Building Integrated Photovoltaics (BIPV) " Solar Design Associates, (10/19/2016) 
[15] Atwah M, Abdulrahman $\mathrm{H}$ \& el Aomre H, Preferred Methods for Incorporating Photovoltaic Cells into the Roofs of Buildings An Analytical Study of Buildings of Popular Housing in Qena City, Journal Of Al Azhar University Engineering Secto,(2017).

[16] JosephB , Pogrebnaya T,\& Kichonge B , "Semitransparent Building-Integrated Photovoltaic: Review on Energy Performance, Challenges, and Future Potential", Hindawi International Journal of Photoenergy Volume 2019, Article ID 5214150, 17 pages , (2019).

[17] Kumar, N. M., Sudhakar, K., \& Samykano, M, "Performance comparison of BAPV and BIPV systems with c-Si", CIS and CdTe photovoltaic technologies under tropical weather conditions. Case Studies in Thermal Engineering, 13, 100374 , (2019).

[18] Thwini.A, "Place and architecture", Publisher Arab Press Agency,(2019).

[19] Khan, H. S., Asif, M., \& Mohammed, M. A. "Case study of a nearly zero energy building in Italian climatic conditions". Infrastructures, 2(4), 19, (2017).

[20] Ghaffarianhoseini, A., AlWaer, H., Omrany, H., Ghaffarianhoseini, A., Alalouch, C., ClementsCroome, D., \& Tookey, J. "Sick building syndrome: are we doing enough?". Architectural Science Review, 61(3), 99-121, (2018).
[21] Roudi, F. (2015). "Understanding Net Zero Energy Building Concept Through Precedents from Different Climate Zones" (Master's thesis, Eastern Mediterranean University (EMU)-Doğu Akdeniz Üniversitesi (DAÜ)), (2015). 